\title{
Gas Exchange and Photochemical Efficiency of Caatinga Plants Submitted to Different Water Management Strategies
}

\author{
Lennon Kledson dos Santos Silva ${ }^{1}$, Maria Claudjane Jerônimo Leite Alves ${ }^{1}$, Renato Nunes Costa ${ }^{2}$, \\ Dayane Mércia Ribeiro Silva ${ }^{2}$, Jania Claudia Camilo dos Santos ${ }^{2}$, Flávia de Barros Prado Moura ${ }^{3}$, \\ Jessé Marques da Silva Júnior ${ }^{1} \&$ José Vieira Silva ${ }^{1}$ \\ ${ }^{1}$ Department of Plant Physiology, Federal University of Alagoas, Arapiraca, Alagoas, Brazil \\ ${ }^{2}$ Department of Production and Plant Improvement, State University of São Paulo Julio de Mesquita Filho, \\ Botucatu, São Paulo, Brazil \\ ${ }^{3}$ Institute of Biological Sciences and Health, Federal University of Alagoas, Maceió, Alagoas, Brazil \\ Correspondence: Lennon Kledson dos Santos Silva, Department of Plant Physiology, Federal University of \\ Alagoas, Arapiraca, Alagoas, Brazil. E-mail: kledson.lennon@hotmail.com
}

Received: March 20, 2019

doi:10.5539/jas.v11n11p53

\begin{abstract}
Water availability is a critical point for dryland recovered on tropical regions of the world. This problem to become higher with the lacking information about the ecophysiologial behavior of the native plants on the initial growth stage under field conditions, mainly when these plants are submitted to different water availability levels. To address this question, we evaluated different water management strategies on the ecophysiological features of the five young native plants establishment in a degraded area located in the Caatinga, a dryland Brazilian forest. The water management strategies effects on native plants were checked by analyzing the photosynthesis rates, gas exchange and photochemistry efficiency in leaves of Crataeva tapia, Erythrina mulungu, Handroanthus impetiginosus, Tabebuia aurea and Ziziphus joazeiro. The experiment had four treatments (waterbox use, bovine manure, hydrogel, bovine manure plus hydrogel) and control. In the initial growth stage and under field conditions, the effects of water stress or water deficiency on the photosynthetic rates, gas exchange and chlorophyll fluorescence $a$ of the T. aurea, H. impetiginosus, C. tapia and E. mulungu, exposed to waterbox and hydrogel, associated or not with bovine manure, were partially or totally mitigated. The Z. joazeiro species has the adaptive intrinsic characteristics that allow them to with stand the most stressful environmental conditions and this naturally allowed presenting greater water use efficiency and absence of damage to the photosynthetic apparatus and high $\mathrm{F}_{\mathrm{v}} / \mathrm{F}_{\mathrm{m}}$ ratio. In general, the water management strategies studied have alleviated the effects of water stress, totally or partially, on the ecophysiological processes of young native plants under field conditions.
\end{abstract}

Keywords: chlorophyll fluorescence $a$, ecophysiology, photosynthesis, tree species, water replacement

\section{Introduction}

The Caatinga is a seasonally dry tropical forest that covers approximately $10 \%$ of the Brazilian territory (Araújo Filho, 2014). The Caatinga has a semi-arid climate, with a high annual average temperature, low relative humidity, high evapotranspiration and low rainfall indices with irregular temporal and spatial distributions (Brasil, 2011). Such characteristics provided the growth of a typically xerophilic biota, whose vegetation presents morphophysiological alterations that help in the adaptation to the stressful conditions of the semiarid climate (Aguiar, Souza, Santos, Arêdes, \& Silva, 2016).

The vegetation of the Caatinga has a high level of endemism (Alves, Ribeiro, J. R. Sousa, Barros, \& P. S. Sousa, 2013). In addition, the extreme climatic conditions of the Caatinga limit the multiplication and dispersion of forest species, especially the tree species. Among the physical and climatic factors, the concentrations of $\mathrm{O}_{2}$, $\mathrm{CO}_{2}$, light intensity, temperature and water stand out. The annual precipitation is low and irregular, ranging from 300 to $1000 \mathrm{~mm}$, (Sampaio \& Freitas, 2017). Thus, the high spatial and temporal variability of the precipitation, allied to high temperature, characterize water stress as the main biophysical variable that determines the survival of the seedlings (Moura, Malhado, \& Ladle, 2013). 
The reduced water availability also causes direct effects on the photosynthetic capacity of the plants, affecting the biochemical reactions, reducing the gas exchange and photochemical efficiency of photosystem II (Campelo et al., 2015).

The use of alternative water management strategies, based on survival irrigation, the use of simple hydrophilic polymers (hydrogels) or associated with nitrogen fertilization, can reduce the level of water stress and increase the percentage of survival of native plants during the dry season in the Caatinga, mainly in the first year of planting, which is considered considered the most critical period after seedlings are planted (Mews, Sousa, Azevedo, \& Souza, 2015; Felippe et al., 2016). This study evaluates the efficiency of the water management strategies regarding the success of tree species in a degraded seasonally dry forest. The study focuses on gas exchange, photosynthetic and photochemical indices of the plants. For this research, representative tree seedlings of dry tropical forests in Brazil were used: Crataeva tapia L., Erythrina mulungu Mart., Handroanthus impetiginosus Mart. ex DC. Mattos, Tabebuia aurea Silva Manso Benth. \& Hook. F. ex S. Moore and Ziziphus joazeiro Mart.

\section{Material and Methods}

\subsection{Study Area}

The study was carried out in an experimental area located at the Federal University of Alagoas-Arapiraca Campus $\left(09^{\circ} 41^{\prime} 53.6^{\prime \prime} \mathrm{S}, 036^{\circ} 41^{\prime} 26.3^{\prime \prime} \mathrm{W}\right.$ and $308 \mathrm{~m}$ altitude), in the period from May to September, 2016, including periods of higher and lower water availability and global solar radiation in the region (Figures $1 \mathrm{~A}$ and 1B). The local climate is tropical rainy type with dry summer (Köppen, 1948), with average annual rainfall ranging from $750 \mathrm{~mm}$ to $1000 \mathrm{~mm}$ (Xavier \& Dornellas, 2005).

The temperature, relative humidity and rainfall for the study period were obtained from an automatic weather station installed in an open grassed area about $200 \mathrm{~m}$ from the experimental area. The soil water content and actual evapotranspiration were obtained from CPTEC (CPTEC, 2016).
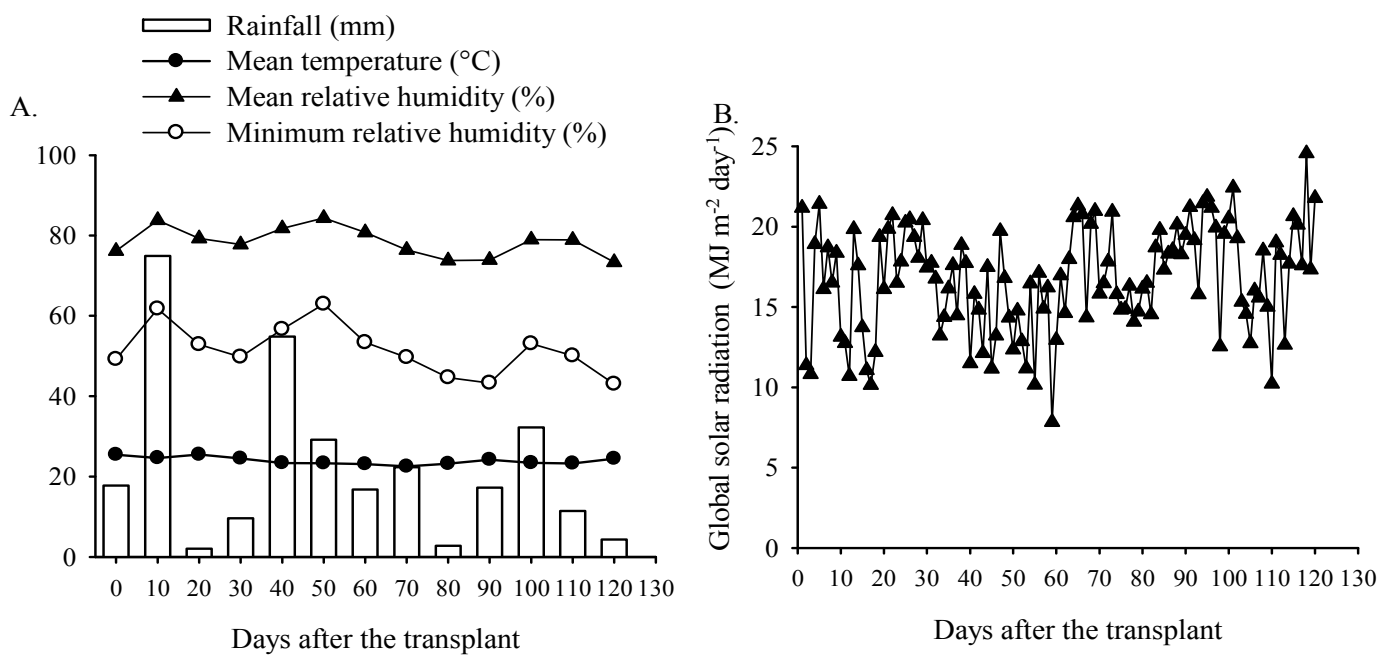

Figure 1. Rainfall $(\mathrm{mm})$, mean temperature $\left({ }^{\circ} \mathrm{C}\right)$, mean relative humidity $(\%)$, minimum relative humidity $(\%)$ and global solar radiation $\left(\mathrm{MJ} \mathrm{m}^{-2}\right.$ day $\left.^{-1}\right)$

\subsection{Experimental Design in the Study Area}

The experimental design was a randomized block design (RBD), where we evaluated different water management strategies on the ecophysiological features of the five young plants native. The species used had four months old, these being: Crataeva tapia, Erythrina mulungu, Handroanthus impetiginosus, Tabebuia aurea e Ziziphus joazeiro, which were transferred to experimental area and planted in pits with $30 \times 30 \times 40 \mathrm{~cm}$. The experiment was consisted of four blocks and each block contained 25 plants, distributed in five lines, spaced in 3 $\mathrm{m}$, with a total area of $144 \mathrm{~m}^{2}$, and the total experimental area consisting of $684 \mathrm{~m}^{2}$. The treatments were: control (CT) where the plants were planted without any treatment, waterbox (WB), bovine manure (EB) with $2.5 \mathrm{~L}$ hole $^{-1}$, hydrophilic polymer, known as hydrogel (HG) $3 \mathrm{~g} \mathrm{hole}^{-1}$ and bovine manure $(2.5 \mathrm{~L})$ plus hydrogel $(3 \mathrm{~g})$ (HE). The experiment was evaluated at 30,60 and 120 days after transplanting (DAT). 


\subsection{Soil and Bovine Manure Analyses}

The soil of the experimental area was characterized according to the analysis of the physical-chemical attributes of the soil samples (Table 1). In the analysis of bovine manure the following nutrient contents were found: $1.39 \mathrm{~g}$ $\mathrm{kg}^{-1}$ of $\mathrm{N} ; 0.58 \mathrm{~g} \mathrm{~kg}^{-1}$ of $\mathrm{P}$ and $0.48 \mathrm{~g} \mathrm{~kg}^{-1}$ of $\mathrm{K}$.

Table 1. Physical-chemical attributes of soil samples at depths of $0-20 \mathrm{~cm}$ and $20-40 \mathrm{~cm}$ in the experimental area

\begin{tabular}{lllc}
\hline \multirow{2}{*}{ Physical characteristics } & \multirow{2}{*}{ Unit } & \multicolumn{2}{c}{ Depth (cm) } \\
\cline { 3 - 4 } Coarse sand & $\mathrm{g} / \mathrm{Kg}$ & 273 & 20 to 40 \\
Thin sand & $\mathrm{g} / \mathrm{Kg}$ & 269 & 280 \\
Total sand & $\mathrm{g} / \mathrm{Kg}$ & 542 & 544 \\
Silte & $\mathrm{g} / \mathrm{Kg}$ & 273 & 259 \\
Clay & $\mathrm{g} / \mathrm{Kg}$ & 186 & 186 \\
Textural class & - & Sandy franc & Sandy franc \\
\hline & $\mathrm{Unit}$ & & Depth $(\mathrm{cm})$ \\
$\mathrm{Chemical} \mathrm{Characteristics}$ & & 0 to 20 & 20 to 40 \\
\hline $\mathrm{pH}$ (in water) & - & 5.60 & 5.50 \\
$\mathrm{Na}$ & $\mathrm{mg} / \mathrm{dm}^{+}$ & 14.00 & 13.00 \\
$\mathrm{P}$ & $\mathrm{mg} / \mathrm{dm}^{3}$ & 11.00 & 10.00 \\
$\mathrm{~K}^{+}$ & $\mathrm{mg} / \mathrm{dm}^{3}$ & 52.00 & 50.00 \\
$\mathrm{Ca}^{2+}$ & $\mathrm{cmol} / \mathrm{dm}^{3}$ & 1.00 & 0.90 \\
$\mathrm{Mg}^{2+}$ & $\mathrm{cmol} / \mathrm{dm}^{3}$ & 0.60 & 0.50 \\
$\mathrm{Al}^{3+}$ & $\mathrm{cmol} / \mathrm{dm}^{3}$ & 0.02 & 0.02 \\
$\mathrm{H}^{+} \mathrm{Al}$ & $\mathrm{cmol} / \mathrm{dm}^{3}$ & 0.70 & 0.70 \\
$\mathrm{Organic}^{3}$ matter & $\%$ & 1.12 & 0.81 \\
\hline
\end{tabular}

Note. $\mathrm{pH}=\mathrm{pH}$ in water, $\mathrm{Na}^{+}=$Sodium, $\mathrm{P}=$ Phosphorus, $\mathrm{K}^{+}=$Potassium, $\mathrm{Ca}^{2+}=$ Calcium, $\mathrm{Mg}^{2+}=$ Magnesium, $\mathrm{Al}^{3+}=$ Aluminium, $\mathrm{H}+\mathrm{Al}=$ Hydrogen + Aluminium .

\subsection{Growth Analysis Were Performed at 30, 60 and 120 DAT}

The following parameters were evaluated: stem basal diameter (SBD) was evaluated using a digital caliper (LEE Tools inox, $150 \mathrm{~mm}$ ); the plant height $(\mathrm{PH})$, from the stem base to the insertion of first youngest leaf of the apex, with the aid of a millimeter ruler, and quantified the number of fully expanded leaves (LN) of the species under study.

\subsection{Gas Exchange and Chlorophyll Fluorescence Analysis}

The gas exchange were measured using an Infrared Gas Analyzer (IRGA) (LI 6400, LICOR, Lincoln, USA), with a specific photosynthetic photon flux density (PPFD) for each of the five species according to previously performed light curve: T. aurea $\left(1600 \mu \mathrm{mol}\right.$ photon $\left.\mathrm{m}^{-2} \mathrm{~s}^{-1}\right), H$. impetiginosus $\left(1000 \mu \mathrm{mol}\right.$ photon $\left.\mathrm{m}^{-2} \mathrm{~s}^{-1}\right), C$. tapia $\left(1800 \mu \mathrm{mol}\right.$ photon $\left.\mathrm{m}^{-2} \mathrm{~s}^{-1}\right)$, E. mulungu $\left(1600 \mu \mathrm{mol}\right.$ photon $\left.\mathrm{m}^{-2} \mathrm{~s}^{-1}\right)$ and Z. joazeiro $\left(1700 \mu \mathrm{mol}\right.$ photon $\mathrm{m}^{-2}$

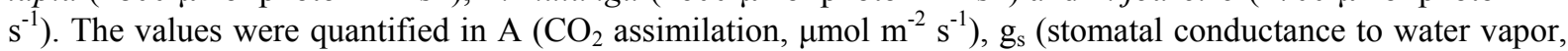
$\mathrm{mol} \mathrm{m} \mathrm{s}^{-1}$ ), E (transpiration, mmol m${ }^{-2} \mathrm{~s}^{-1}$ ), and to obtain the water use efficiency $\left(\mathrm{A} / \mathrm{E}, \mu \mathrm{mol} \mathrm{CO} \mathrm{Cmol}^{-1} \mathrm{H}_{2} \mathrm{O}\right.$ ) A was divided by $\mathrm{E}$ (Osmond, Björkman, \& Anderson, 1980).

To evaluate the fluorescence variations of chlorophyll $a$, the leaves were placed in the dark for 30 minutes and in these leaves the minimum chlorophyll fluorescence $\left(\mathrm{F}_{\mathrm{o}}\right)$ was determined. Then, the maximum fluorescence $\left(\mathrm{F}_{\mathrm{m}}\right)$ was obtained with a saturating pulse of actinic light at $\sim 7800 \mu \mathrm{mol} \mathrm{m}^{-2} \mathrm{~s}^{-1}$. Fluorescence emission in a stable state $\left(F_{t}\right)$ and maximum fluorescence emission $\left(F_{m}^{\prime}\right)$ were determined for light-adapted sheets subjected to stable photosynthesis. From these data, the following photochemical parameters were calculated: maximum photochemical efficiency of $\phi_{\text {PSII }}\left[\mathrm{F}_{\mathrm{v}} / \mathrm{F}_{\mathrm{m}}=\left(\mathrm{F}_{\mathrm{m}}-\mathrm{F}_{\mathrm{o}}\right) / \mathrm{F}_{\mathrm{m}}\right]$, quantum yield of photosystem II expressed as PSII $=$ $F_{m}^{\prime}-F_{t} / F_{m}^{\prime}$, photochemical extinction coefficient $\left[P Q=\left(F_{m}^{\prime}-F_{t}\right) /\left(F_{m}^{\prime}-F_{0}^{\prime}\right)\right]$ and non-photochemical extinction coefficient $\left.\left[\mathrm{NPQ}=\left(\mathrm{F}_{\mathrm{m}}-\mathrm{F}_{\mathrm{m}}{ }_{\mathrm{m}}\right) / \mathrm{F}_{\mathrm{m}}{ }_{\mathrm{m}}\right)\right]$ (Maxwell \& Johnson, 2000).

\subsection{Statistical Analysis}


The data were submitted to analysis of variance and the means compared by the test Tukey the $5 \%$ probability, using the statistical program SISVAR, version 5.6 build 86 (Ferreira, 2014). To perform the principal component analysis (PCA) we used the Paleontological Statistics Software-PAST, version, 3.18.

\section{Results}

\subsection{Climatological Characterization}

During the experimental period, total precipitation was $295.64 \mathrm{~mm}$ with a maximum of $92.71 \mathrm{~mm}$ in the month of May 2016 and a minimum of $15.75 \mathrm{~mm}$ in the month of September 2016 and an average temperature of $24.9^{\circ} \mathrm{C}$ (Figure 1A). There was a period of higher (40 DAT) and lower (120 DAT) availability of water in the soil (Figure 2A). A higher AET was also found at $35(3.41 \mathrm{~mm})$ and $53(3.69 \mathrm{~mm})$ DAT. In general, AET was higher in the period from 30 to $50 \mathrm{DAT}$ due to the greater availability of water in the environment (Figures $2 \mathrm{~A}$ and $2 \mathrm{~B})$.

A.

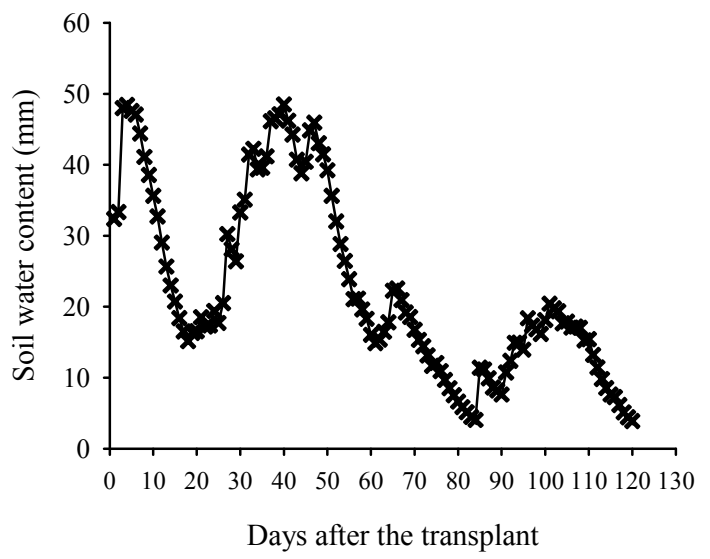

B.

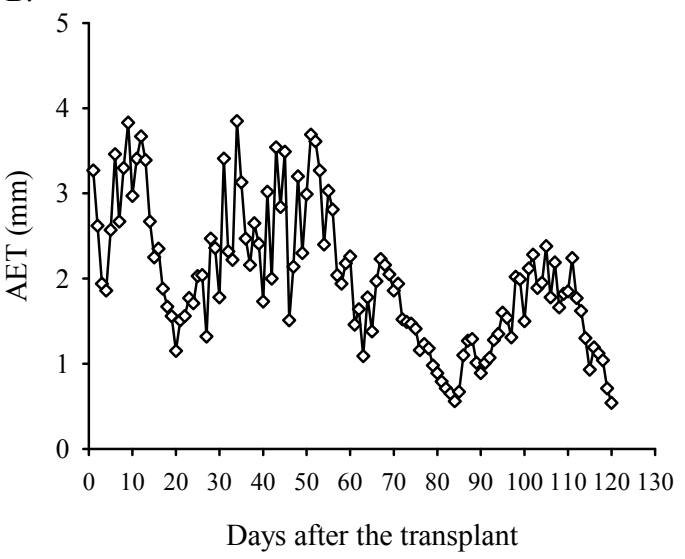

Figure 2. Soil water content $(\mathrm{mm})$ and actual evapotranspiration $(\mathrm{mm})$ in the period from May to September, 2016, including periods of higher and lower water availability

\subsection{Plant Growth}

The management of seedlings of native species under field conditions with the use of soil conditioner (HG), bovine manure (EB) and controlled water dispersion or waterbox (WB) system had a positive influence on the biometric parameters of the species studied. At $30 \mathrm{DAT}$, T. aurea plants submitted to WB and HE treatments presented increases of $50 \%$ in leaf number $(\mathrm{LN})$, while in plants under treatments $\mathrm{EB}$ and $\mathrm{HG}$, these increases were $30 \%$, in relation to control plants (CT) (Figure 3A). However, at 60 DAT, a reduction of $25 \%$ in the LN of the plants that received only HG was verified, whereas in the EB treatment plants there was an increase of $16.67 \%$ in the LN. The difference in height of the T. aurea plants was verified only from 60 DAT, since the plants submitted to EB and HE treatments had increases of $48.75 \%$ and $42.46 \%$, respectively, in relation to the CT (Figure 3B). In relation to the stem diameter, it is possible to verify the positive effect of the 120 DAT for the plants submitted to the HE treatment, in relation to the control plants, with an increase of $46.3 \%$ (Figure 3C).

For H. impetiginosus the maximum $\mathrm{LN}$ in all treatments occurred at $30 \mathrm{DAT}$, and no significant differences were observed in this variable among the treatments in this period. From the 60 DAT, however, there was a reduction of LN in plants of treatments CT, EB and HE, whose percentages reached $33.3 \%, 25.0 \%$ and $23.1 \%$, respectively, while in the plants submitted to WB and HG, the LN remained constant until 90 DAT (Figure 3D).

For C. tapia, the maximum number of leaves was observed at 30 DAT for plants submitted to WB (Figure 3G). In addition, it was verified that the application of the HG treatment, in relation to the CT, promoted a positive effect on the height of the plants, increasing already from the 30 DAT, with an increase of $41.5 \%$. In subsequent evaluations performed at 60 and $120 \mathrm{DAT}$, these variations in plant height of the HG treatment with respect to CT were increasing, whose percentages of increase were $38.7 \%$ and $37.1 \%$, respectively (Figure $3 \mathrm{H}$ ). Regarding the stem diameter, the plants submitted to WB treatment had increases of $30.72 \%$ in relation to the CT plants at 120 DAT (Figure 3I). 

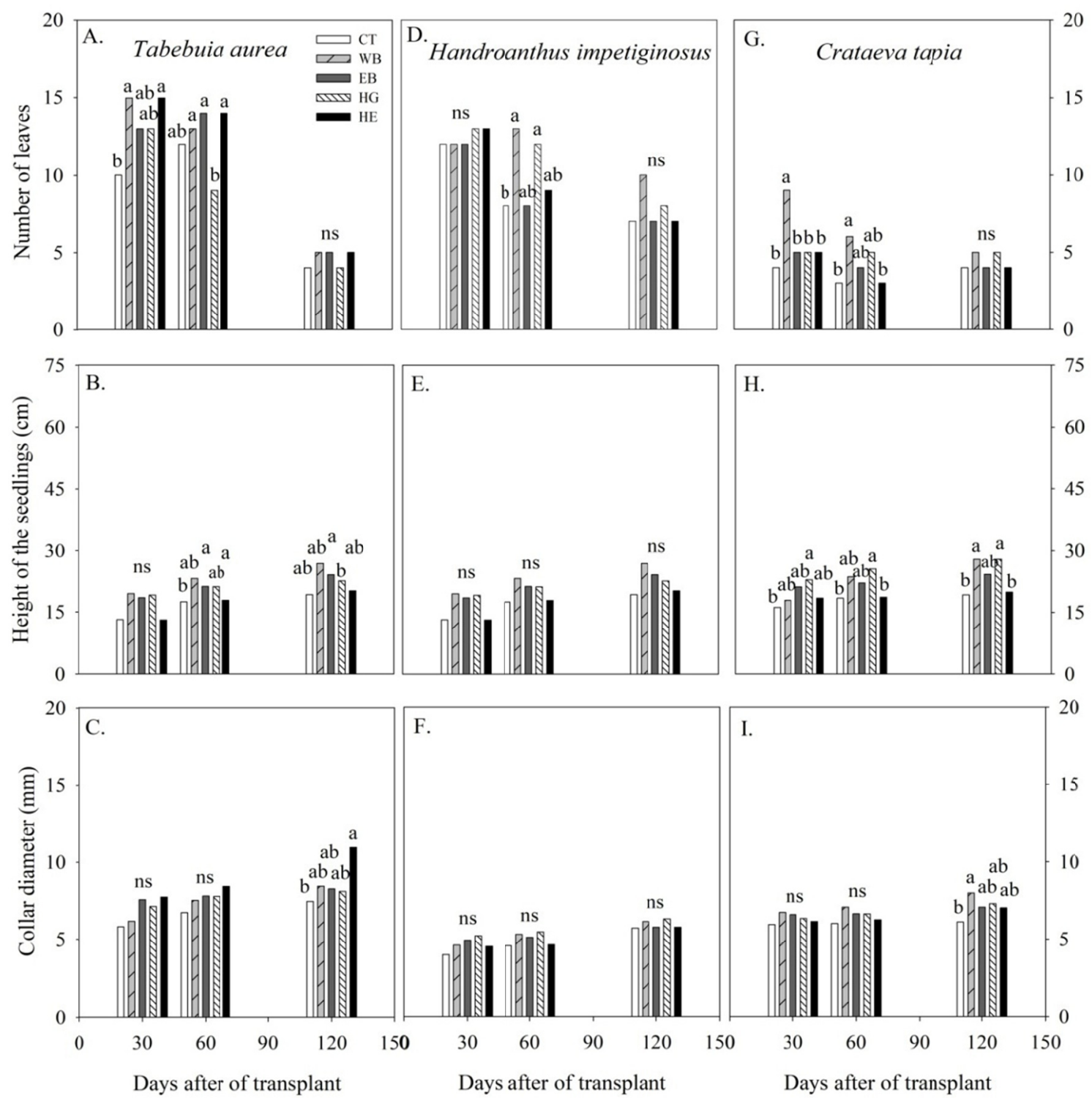

Figure 3. Number of leaves, height of seedlings and collar diameter of Tabebuia aurea (A, B, C), Handroanthus impetiginosus (D, E, F) and Crataeva tapia (G, H, I). Lowercase letters indicate significant differences by the Tukey test $(\mathrm{p}<0.05)$ among the evaluated treatments

From 30 DAT, the height of E. mulungu plants was higher in treatments with the use of isolated hydrogel (HG) and hydrogel combined with bovine manure (HE). In the three evaluations performed 30, 60 and 120 DAT, the use of the hydrogel allowed increases of $32.9 \%, 50.0 \%$ and $36.3 \%$, in relation to the control (CT), whereas in the plants where the association of the hydrogel and bovine manure these increases were $55.3 \%, 55.3 \%$ and $44.1 \%$, respectively (Figure 4B).

For Z. joazeiro the use of WB promoted a $46.4 \%$ increase in plant diameter from 60 DAT when compared to control (CT). The superior performance of plants submitted to WB was maintained at 120 DAT with a $34.6 \%$ increase in relation to the control (Figure 4F). 

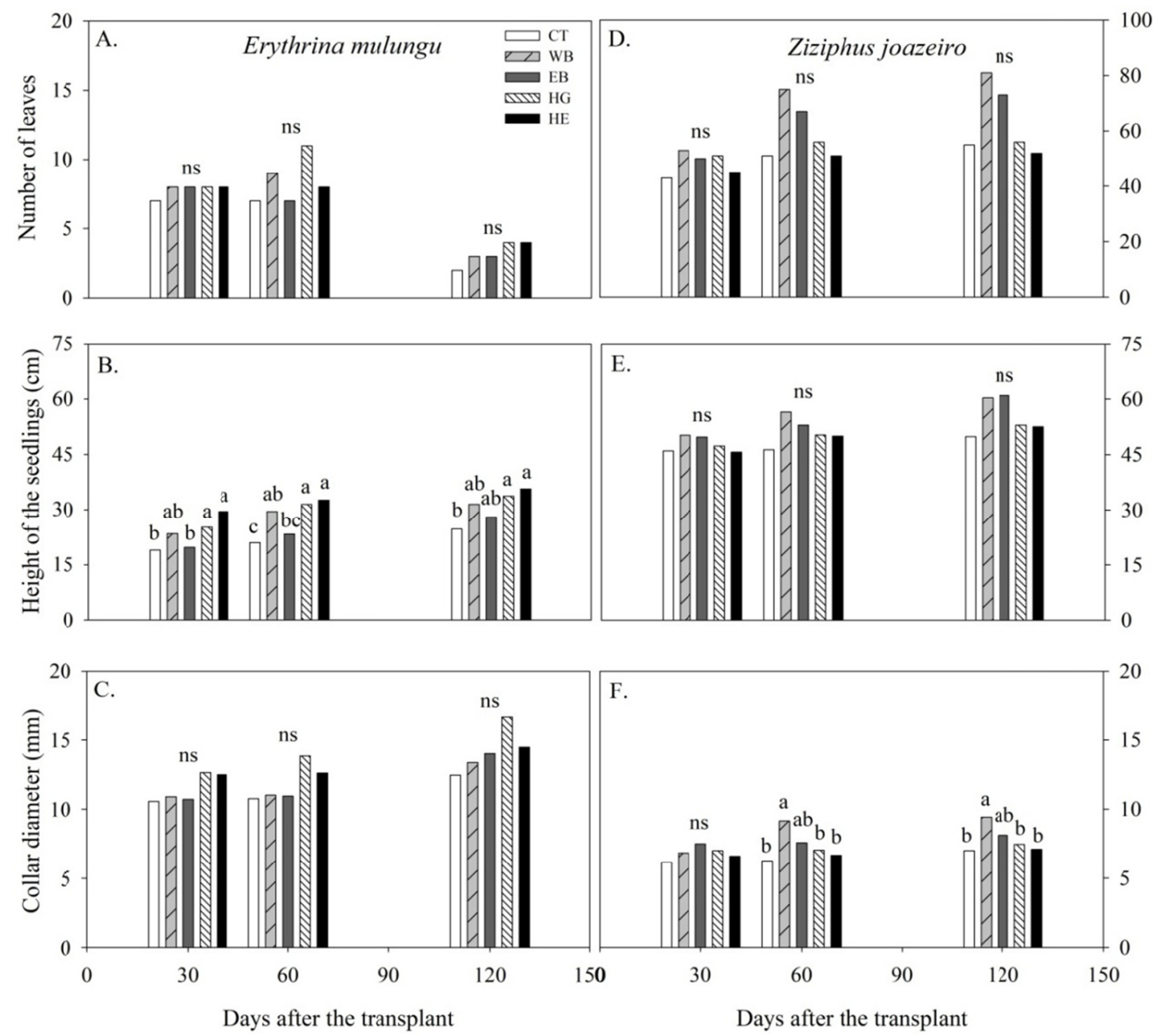

Figure 4. Number of leaves, height of seedlings and collar diameter of Erythrina mulungu (A, B, C) and Ziziphus joazeiro $(\mathrm{D}, \mathrm{E}, \mathrm{F})$. Lowercase letters indicate significant differences by the Tukey test $(\mathrm{p}<0.05)$ among the evaluated treatments

\subsection{Gas Exchange and Chlorophyll Fluorescence Analysis}

From the 30 DAT, significant differences were observed in the gas exchange and chlorophyll fluorescence for the five species evaluated. However, at 120 DAT, there were more pronounced differences.

In T. aurea, differences in phisiological parameters were more pronounced at $120 \mathrm{DAT}$ (Figures 5A, 5B, 5C, 6B, and $6 \mathrm{D}$ ). At this point, there was a $238.5 \%$ increase in the A rate in relation to the control plants (CT) when they were submitted to waterbox (WB) application. When bovine manure (EB) or hydrogel alone (HG) was applied, there was no significant change of the A rate in the plants. However, when the application occurred in association with manure and hydrogel (HE), a significant increase in the photosynthetic rate of the plants $(125.5 \%)$ was observed, indicating an additive effect when compared to the control treatment plants. Similar to $\mathrm{A}$, the $\mathrm{g}_{\mathrm{s}}$ and $\mathrm{E}$ variables of the WB treatment plants increased $325 \%$ and $178 \%$, respectively, compared to the control plants (Figures 5A and 5C). When compared to photochemistry of plants, it was observed that PSII presented increase in WB and HE treatments in $70.6 \%$ and $53 \%$, respectively (Figure 6B), whereas NPQ was reduced, evidencing that there was less heat production in the form of infrared radiation (Figure 6D).

In an analogous way, it was verified that in the species $H$. impetiginosus the differences were more accentuated to $120 \mathrm{DAT}$. In this period, the isolated application of $\mathrm{HG}$ was similar to $\mathrm{WB}$, promoting substantial increases in the analyzed variables. The A rate was increased by $152.4 \%$ in the WB and HG treatments plants relative to CT after 120 DAT (Figure 5F). The values of $g_{s}$ and $\mathrm{E}$ were also increased by $155.4 \%$ and $129.4 \%$, respectively, in HG treatment plants when compared to CT (Figures 5E and 5G). In the photochemical parameters the plants of the WB and HG treatment presented higher PSII performance (91\%) than the control at 120 DAT (Figure 6F). 
In relation to the species $C$. tapia, it was verified that the most expressive differences occurred from 60 DAT. In this period, similar to $H$. impetiginosus, the isolated application of HG was also similar to waterbox (WB), promoting substantial increases in the analyzed variables. Rates of $\mathrm{A}$ and $\mathrm{g}_{\mathrm{s}}$ were increased by $51.22 \%$ and $55.14 \%$, respectively, relative to CT (Figures 5I and 5J). In the E. mulungu species the most striking differences occurred in the WB and HG treatments at 60 DAT. In this period, similar to H. impetiginosus and C. tapia, the isolated application of HG was analogous to waterbox (WB). However, for the Z. joazeiro species the most pronounced differences occurred at 30 DAT. For this species there was an increase of $121.57 \%$ and $85.54 \%$ in the $\mathrm{A}$ and $\mathrm{A} / \mathrm{E}$ rates, respectively, when compared with $\mathrm{CT}$ (Figures $7 \mathrm{~F}$ and $7 \mathrm{H}$ ).
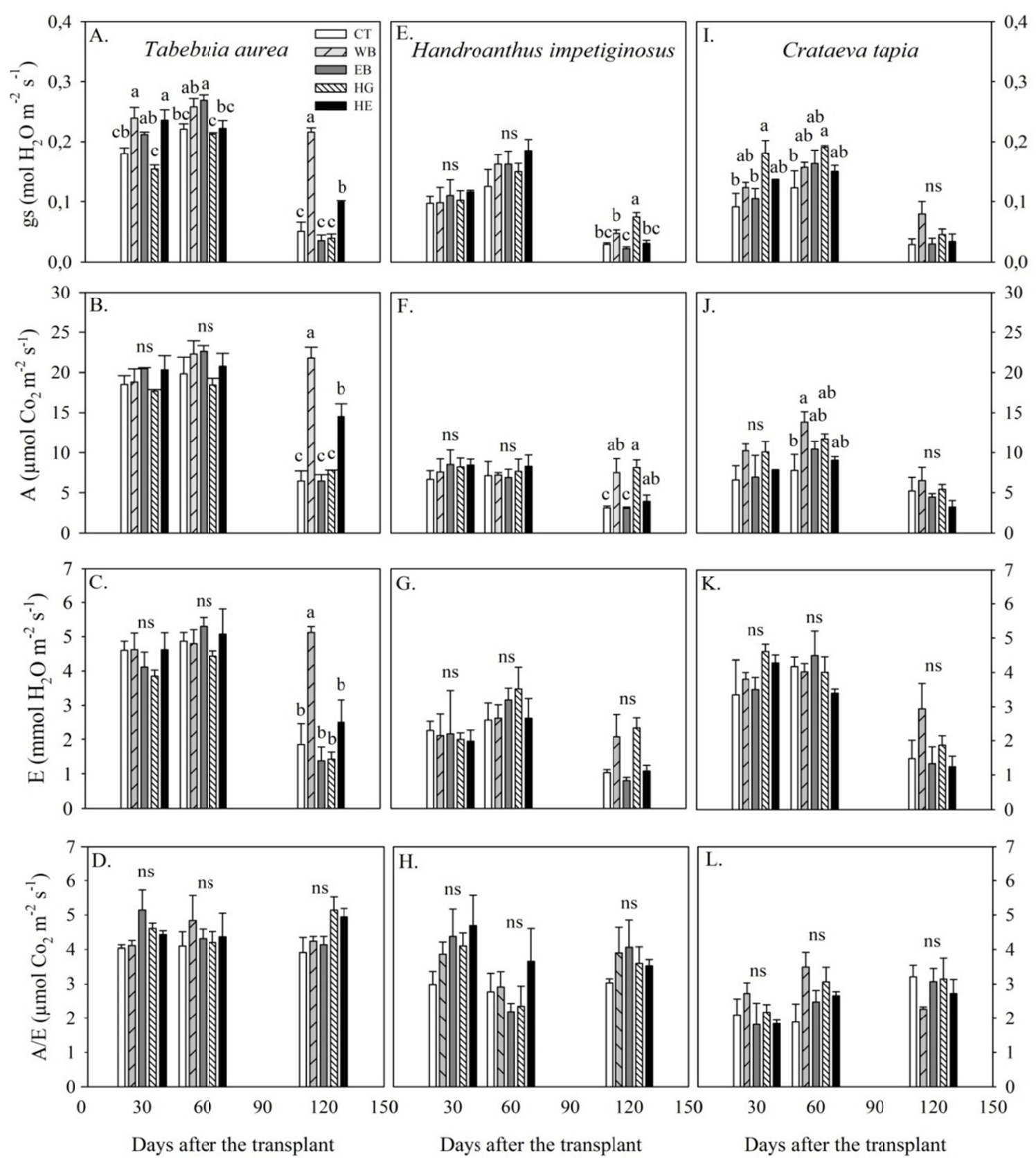

Figure 5. Liquid photosynthesis $(\mathrm{A})$, stomatal conductance $\left(\mathrm{g}_{\mathrm{s}}\right)$, transpiration $(\mathrm{E})$ and water use efficiency $(\mathrm{A} / \mathrm{E})$ in Tabebuia aurea (A, B, C, D), Handroanthus impetiginosus (E, F, G, H) and Crataeva tapia (I, J, K, L).

Values represent mean repetitions $(n=4 \pm S D)$. Lowercase letters indicate significant differences by the Tukey test $(\mathrm{p}<0.05)$ among the evaluated treatments 

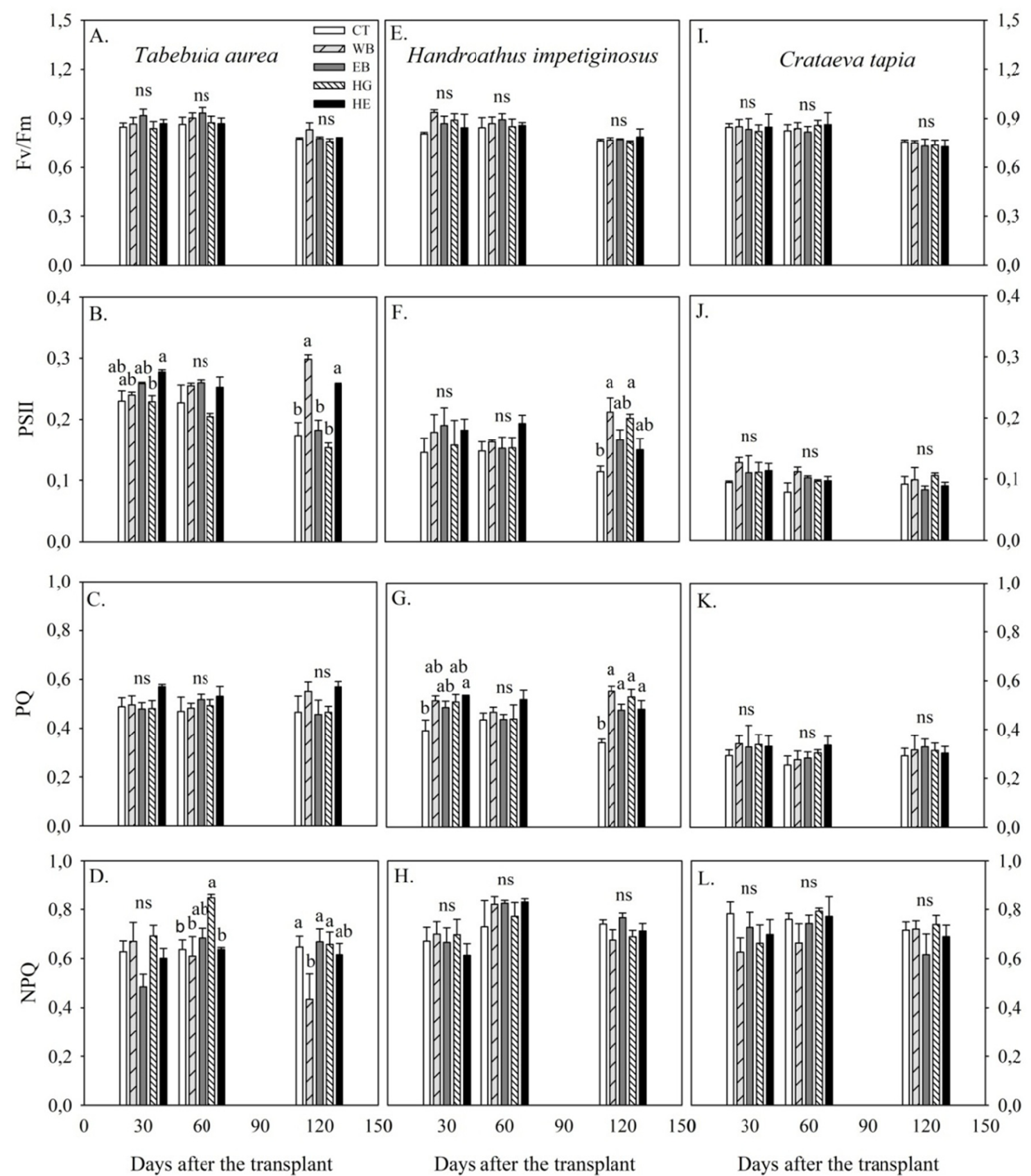

Figure 6. Maximum quantum efficiency of photosystem II $\left(\mathrm{F}_{\mathrm{v}} / \mathrm{F}_{\mathrm{m}}\right)$, maximum effective photochemical efficiency

of photosystem II (PSII), photochemical extinction coefficient (PQ) and non-photochemical extinction coefficient (NPQ) in Tabebuia aurea (A, B, C, D), Handroanthus impetiginosus (E, F, G, H) and Crataeva tapia (I, J, K, L). Values represent mean repetitions $(n=4 \pm S D)$. Lowercase letters indicate significant differences by the Tukey test $(\mathrm{p}<0.05)$ among the evaluated treatments 

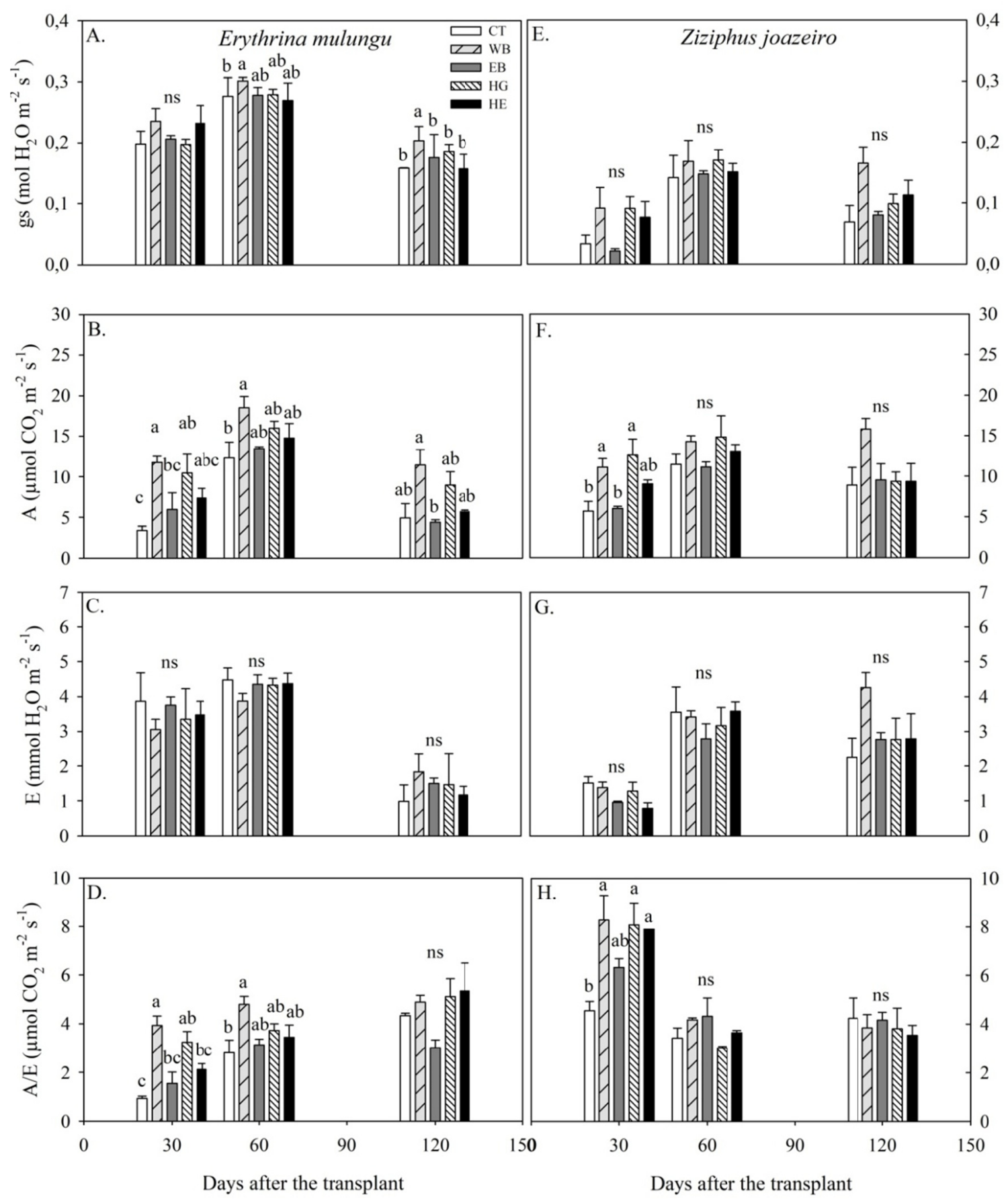

Figure 7. Liquid photosynthesis (A), stomatal conductance $\left(\mathrm{g}_{\mathrm{s}}\right)$, transpiration $(\mathrm{E})$ and water use efficiency (A/E) in Erythrina mulungu (A, B, C, D) and Ziziphus joazeiro (E, F, G, H). Values represent mean repetitions ( $\mathrm{n}=$ $4 \pm S D)$. Lowercase letters indicate significant differences by the Tukey test $(p<0.05)$ among the evaluated treatments 

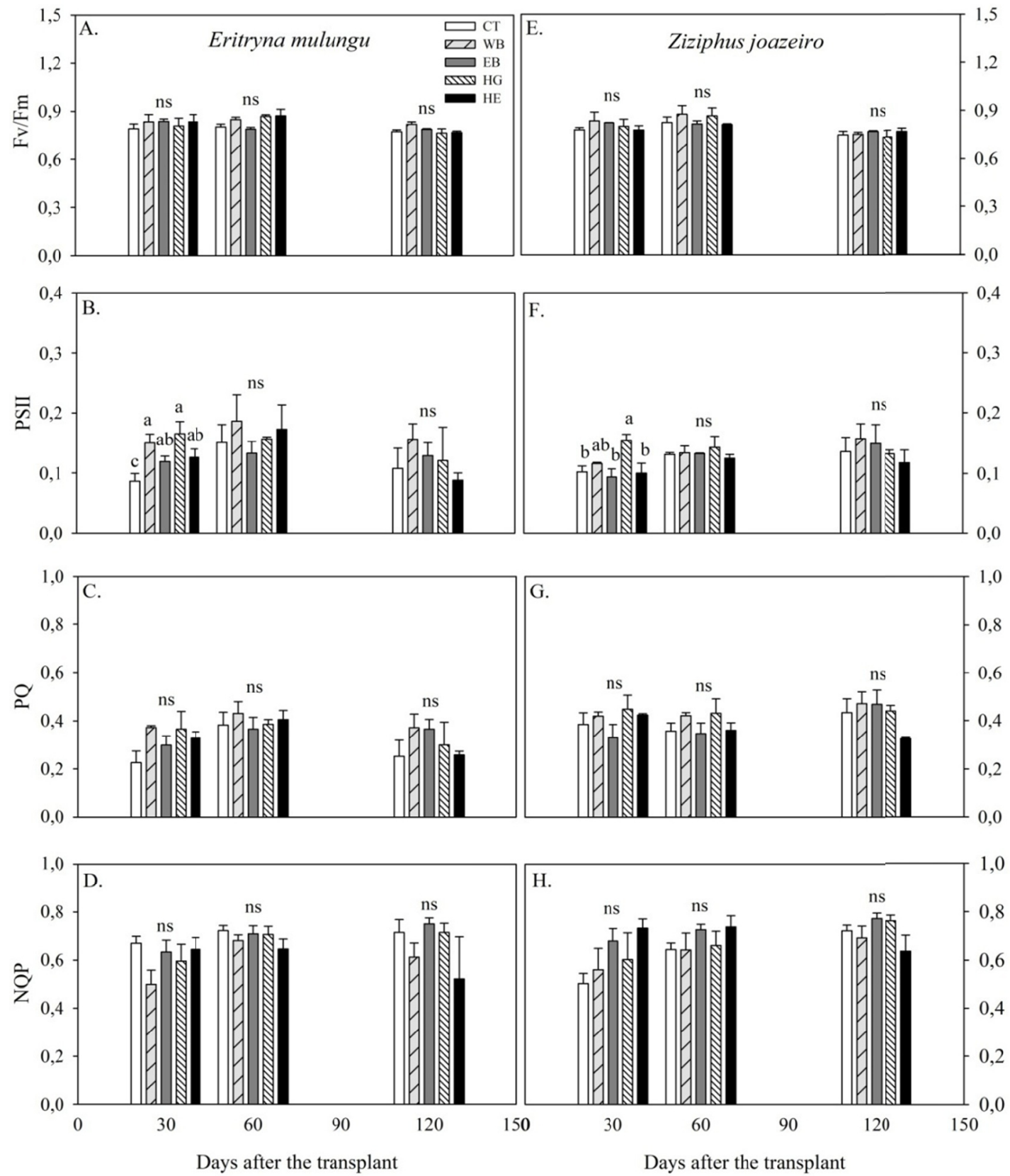

Figure 8. Maximum quantum efficiency of photosystem II $\left(\mathrm{F}_{\mathrm{v}} / \mathrm{F}_{\mathrm{m}}\right)$, maximum effective photochemical efficiency of photosystem II (PSII), photochemical extinction coefficient (PQ) and non-photochemical extinction coefficient (NPQ) in Erythrina mulungu (A, B, C, D) and Ziziphus joazeiro (E, F, G, H). Values represent mean repetitions $(n=4 \pm S D)$. Lowercase letters indicate significant differences by the Tukey test $(p<0.05)$ among the evaluated treatments

Since there were marked differences at 120 DAT for the five species evaluated, a multivariate analysis of main components was carried out in this period, in order to establish the correlation of the photochemical and gas exchange variables with the different treatments applied, in order to allow a better understanding of the correlations between the different treatments applied (Table 2, Figure 9).

\subsection{Principal Component Analysis of Gas Exchange and Chlorophyll Fluorescence}

At $120 \mathrm{DAT}$ it was found that the two main components allowed explaining $70.04 \%$ to $T$. aurea, $70.25 \% \mathrm{H}$. impetiginosus, $66.66 \%$ C. tapia, $66.83 \%$ E. mulungu and $62.67 \%$ Z. Joazeiro of the variance contained in the original variables, presenting eigen values greater than 1 (Table 2, Figure 9). The variables that presented the 
greatest discriminatory power in the main component one (PC1) of the five species were: $\mathrm{g}_{\mathrm{s}}$, A, E e PSII (Table 2). However, in the analysis of main component two (PC2) the variables were: $N P Q, A / E$ and $F_{v} / F_{m}(T a b l e ~ 2)$.

Variables with the same sign act directly, that is, when the value of one increases the value of the other increases, or vice versa, and those with opposite signs act in reverse, that is, when the value of one increases, the value of the other decreases. Thus, the variables $\mathrm{g}_{\mathrm{s}}, \mathrm{A}, \mathrm{E}$ and PSII act directly and inversely to the NPQ and A/E (Table 2). Thus, these photochemical and gas exchange variables in the first two main components PC1 and PC2 are considered important for the selection of water management strategies for T. aurea, H. impetiginosus, C. tapia, E. mulungu and $Z$. joazeiro. It should be noted that the positive correlations are responsible for the discrimination of the water management strategies located to the right of PC1 (WB and HE), (WB), (HG) and (WB) in T. aurea, H. impetiginosus, C. tapia, E. mulungu and Z. joazeiro, respectively (Figure 9). It should be noted that the discriminatory power of each variable within a main component is measured by the linear correlation between each variable and its main component. The correlation between each variable and the main components (PC1 and PC2), indicates the formation of different groups in the water management strategies (Figure 9). In addition, it is possible to verify that the variables associated with the photochemical phase of photosynthesis and gas exchange are turned to the right in PC1 correlated with these treatments, showing that the main component analysis is an exploratory tool capable of identifying and selecting strategies that can mitigate the harmful effects on plants resulting from periods of water shortage.

Table 2. Correlation between the main components (PC1, PC2) and the photochemical and gas exchange variables of the species Tabebuia aurea, Handroanthus impetiginosus, Crataeva tapia, Erythrina mulungu and Ziziphus joazeiro, 120 days after transplanting

\begin{tabular}{|c|c|c|}
\hline Principal component (PC) & PC1 & PC2 \\
\hline Eigen values & 4.831 & 1.333 \\
\hline Variance explained $(\%)$ & 60.381 & 16.663 \\
\hline \multicolumn{3}{|l|}{ Correlation } \\
\hline $\mathrm{g}_{\mathrm{s}}$ & 0.961 & 0.022 \\
\hline A & 0.934 & 0.013 \\
\hline E & 0.946 & 0.151 \\
\hline $\mathrm{A} / \mathrm{E}$ & -0.185 & -0.551 \\
\hline $\mathrm{F}_{\mathrm{v}} / \mathrm{F}_{\mathrm{m}}$ & 0.621 & -0.551 \\
\hline PSII & 0.941 & 0.168 \\
\hline PQ & 0.625 & 0.522 \\
\hline NPQ & -0.667 & 0.934 \\
\hline \multicolumn{3}{|l|}{ Handroanthus impetiginosus } \\
\hline Eigen values & 4.288 & 1.332 \\
\hline Variance explained (\%) & 53.605 & 16.650 \\
\hline \multicolumn{3}{|l|}{ Correlation } \\
\hline $\mathrm{g}_{\mathrm{s}}$ & 0.844 & -0.289 \\
\hline A & 0.958 & -0.092 \\
\hline $\mathrm{E}$ & 0.803 & -0.503 \\
\hline $\mathrm{A} / \mathrm{E}$ & 0.271 & 0.840 \\
\hline $\mathrm{F}_{\mathrm{v}} / \mathrm{F}_{\mathrm{m}}$ & -0.101 & 0.340 \\
\hline PSII & 0.908 & 0.176 \\
\hline PQ & 0.784 & 0.265 \\
\hline NPQ & -0.693 & -0.252 \\
\hline \multicolumn{3}{|l|}{ Crataeva tapia } \\
\hline Eigen values & 3.707 & 1.626 \\
\hline Variance explained (\%) & 46.342 & 20.327 \\
\hline \multicolumn{3}{|l|}{ Correlation } \\
\hline$g_{s}$ & 0.879 & -0.068 \\
\hline $\mathrm{A}$ & 0.852 & 0.043 \\
\hline E & 0.964 & 0.068 \\
\hline $\mathrm{A} / \mathrm{E}$ & -0.361 & -0.225 \\
\hline $\mathrm{F}_{\mathrm{v}} / \mathrm{F}_{\mathrm{m}}$ & -0.296 & 0.831 \\
\hline PSII & 0.781 & 0.062 \\
\hline PQ & 0.667 & 0.187 \\
\hline NPQ & -0.056 & 0.913 \\
\hline
\end{tabular}




\begin{tabular}{lll}
\hline Erythrina mulungu & \\
Eigen values & 3.946 & 1.401 \\
Variance explained (\%) & 49.320 & 17.511 \\
Correlation & & \\
$\mathrm{g}_{\mathrm{s}}$ & 0.851 & 0.171 \\
$\mathrm{~A}$ & 0.748 & 0.343 \\
$\mathrm{E}$ & 0.794 & -0.360 \\
$\mathrm{~A} / \mathrm{E}$ & -0.171 & 0.884 \\
$\mathrm{~F}_{\mathrm{v}} / \mathrm{F}_{\mathrm{m}}$ & 0.414 & 0.500 \\
$\mathrm{PSII}$ & 0.852 & -0.104 \\
$\mathrm{PQ}$ & 0.774 & -0.242 \\
$\mathrm{NPQ}$ & -0.709 & -0.145 \\
\hline Ziziphus joazeiro & & \\
Eigen values & 3.509 & 1.504 \\
Variance explained $(\%)$ & 43.872 & 18.803 \\
Correlation & & \\
$\mathrm{g}_{\mathrm{s}}$ & 0.880 & -0.180 \\
$\mathrm{~A}$ & 0.842 & 0.143 \\
$\mathrm{E}$ & 0.925 & -0.101 \\
$\mathrm{~A} / \mathrm{E}$ & -0.325 & 0.438 \\
$\mathrm{~F}_{\mathrm{v}} / \mathrm{F}_{\mathrm{m}}$ & 0.023 & -0.449 \\
$\mathrm{PSII}$ & 0.707 & 0.496 \\
PQ & 0.115 & 0.865 \\
$\mathrm{NPQ}$ & -0.741 & 0.224 \\
\hline
\end{tabular}

Note. $\mathrm{PC} 1=$ Principal component one, $\mathrm{PC} 2$ = Principal component two.
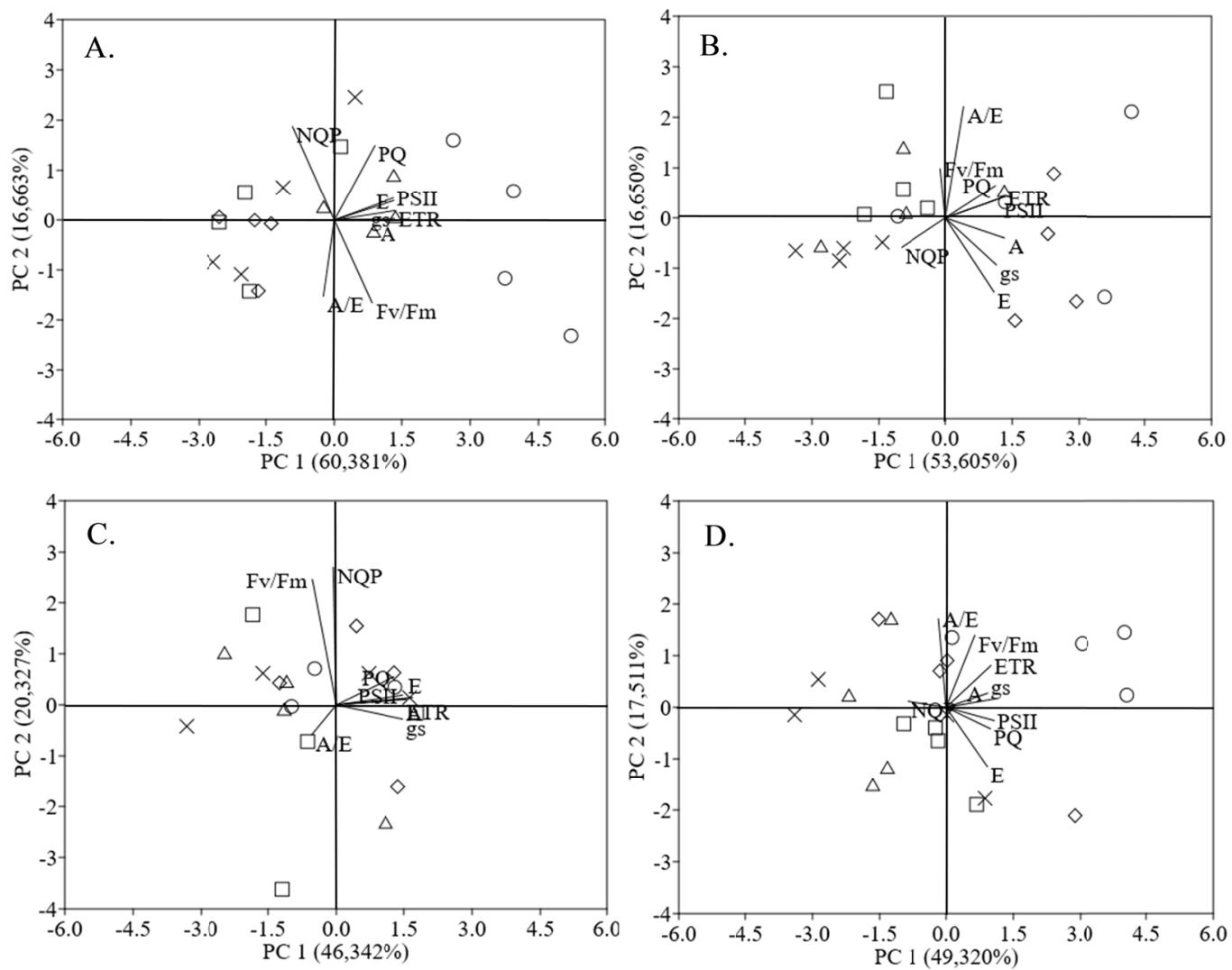


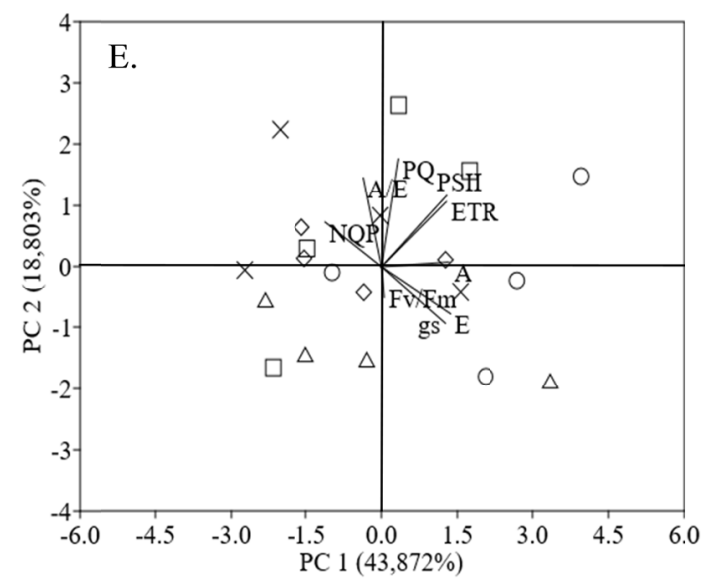

Figure 9. Dispersion (biplot gráfica) of the photochemical and gas exchange variables related to the species: Tabebuia aurea (A), Handroanthus impetiginosus (B), Crataeva tapia (C), Erythrina mulungu (D) and Ziziphus joazeiro (E), at 120 days after transplanting. Treatments: (x) CT (control), (०) WB (waterbox), ( $\square$ ) EB (bovine manure), ( $\diamond) \mathrm{HG}$ (hydrogel) and $(\Delta) \mathrm{HE}$ (hydrogel plus bovine manure). Principal component one (PC1) and principal component two (PC2)

\section{Discussion}

\subsection{Plant Growth}

The number of leaves varied between species and between treatments, but mainly in relation to local precipitation. At 120 DAT, the greatest reduction in leaf numbers occurred for all species. This period coincided with the period of lowest water availability.

For $T$. aurea, only the bovine manure (EB) plants presented a significant increase in height, which may be related to the input of organic matter source provided by this treatment. The addition of organic matter is one of the practices that contribute to the supply of nutrients to the plants and to the improvement of the physical and chemical characteristics of the culture medium (Artur et al., 2007). These results are in agreement with those found by Cruz et al. (2016) when verifying that the substrates containing tanned bovine manure provide significant increases in the height of Spondias tuberosa when compared to those that did not have manure in its composition.

For C. tapia and E. mulungu, the use of the hydrogel alone, or associated with bovine manure, significantly increased the height and stem diameter. Similarly, Mews et al. (2015) verified that the application of the hydrogel incorporated into the substrate associated with nitrogen fertilization positively influenced the growth and quality of the Handroanthus ochraceus seedlings. However, Barbosa et al. (2013) evaluating the isolated use of the hydrogel in establishing seedlings of native forest species, including the genre Tabebuia and Handroathus, verified that there was no effect of the hydrogel in the establishment and neither the growth of the seedlings in the different treatments, for the period in which the experiment was evaluated. In contrast, for the species $C$. tapia and $Z$. joazeiro the stem diameter was increased in the treatment plants that had the controlled water dispersion system (WB).

\subsection{Photochemical Studies and Gas Exchange}

Tabebuia aurea, Handroanthus impetiginosus, Crataeva tapia, Erythrina mulungu and Ziziphus joazeiro are potentially important tree species in dry forest environments such as the Caatinga that can be used to restore degraded and deforested areas. The availability of water had an effect on the physiological responses of the tested species causing and alterations in photosynthesis, photochemistry and gas exchange. In T. aurea, in the period of lower water availability, lower air humidity and higher global radiation (120 DAT), WB and HE treatments promoted better performance in $\mathrm{A}$ rates and $\mathrm{g}_{\mathrm{s}}$ (Figures 1A, 1B, 2A, 5A, and 5B). These results probably occurred due to the gradual distribution of water to the species by WB treatment, thus allowing less stomatal resistance. In the HE treatment, the combination of hydrogel and bovine manure allowed in addition to the gradual distribution of water the addition of nutrients necessary for the growth of the plant.

In the period of lower precipitation (Figures 1A and 1B), transpiration rates were also reduced through restriction mechanisms. In the T. aurea species, the reduction of precipitation at 120 DAT induced the plants to decrease 
the rate of transpiration in response to stomatal closure, this important behavior helps the plant to maintain the integrity of its cells and membranes (Larcher, 2004; Oliveira, Gualtieri, \& Bocchese, 2011). In addition, at 120 DAT the water availability promoted by the waterbox may have aided in the reduction of the $\mathrm{T}_{\mathrm{f}}$ in the plants of the WB treatment, not affecting the photosynthetic functions due to the non-change in the $\mathrm{CO}_{2}$ fixation rates, phosphorylation and electron transport.

For Salinas et al. (1996) reductions in E rates induce increase in leaf temperature, which in turn has a negative influence on latent heat dissipation. Therefore, the increase of leaf transpiration in $T$. aurea correlates with the increase of $g_{s}$ values and the A rate in response to available water in the soil (Oliveira \& Gualtierri, 2016).

Similar results from the correlation da $\mathrm{g}_{\mathrm{s}}$, A and $\mathrm{E}$ with soil water availability in $T$. aurea were also observed by Oliveira et al. (2011). These authors observed that after 14 days of irrigation suppression, the de $g_{s}$ values and the $\mathrm{A}$ and $\mathrm{E}$ rates were zero, and after four days of plant rehydration the values of these parameters were similar to the beginning of the experiment, indicating the ability of the species to tolerate the hydric deficit during a certain period. This ability to tolerate the hydric deficit for a longer period may be related to the ability of this species to use the available water of the soil more efficiently as observed in this study, that over the 120 days of observation the values of $\mathrm{A} / \mathrm{E}$ were unchanged in the different treatments evaluated.

The high maximum effective photochemical efficiency of PSII (PSII) and the high non-photochemical extinction coefficient (NPQ) in plants of the T. aurea WB treatment at 120 DAT may be related to the absence of changes in the quantum efficiency of the photosystem II $\left(\mathrm{F}_{\mathrm{v}} / \mathrm{F}_{\mathrm{m}}\right)$ in response to water availability in the soil provided by the waterbox. In healthy and non-stressed plants the $F_{v} / F_{m}$ ranges between 0.75 and 0.85 and the drop in these values may be indicative of photoinhibitory damage in the PSII reaction centers (Bolhàr-Nordenkampf et al., 1989; Lage-Pinto, Bemini, Oliveira, \& Vitória, 2012). This ability to maintain similar values in the $F_{v} / F_{m}$ under water stress in $T$. aurea suggests that most of the radiation may be used in the photochemical phase of photosynthesis, probably by the carbon assimilation reactions (Gonçalves et al., 2010).

In the species $H$. impetiginosus, $C$. tapia and E. mulungu increased water availability promoted by both WB and HG may have contributed to promote the highest values in the parameters of $\mathrm{A}, \mathrm{g}_{\mathrm{s}}$ and $\mathrm{E}$ at 120 DAT (Table 2 and Figure 9). We suggest that the use of the hydrogel in planting practices supports the hypothesis of soil water storage and availability during periods of lower rainfall in the semiarid environment. Similar results were observed by Arbona et al. (2005) that studying citrus plants observed an increase in the growth rates and photosynthesis of the hydrogel treated plants. In addition Chirino et al. (2011) demonstrated that the application of the hydrogel promoted a positive effect on Quercus suber seedlings after 20 months of planting, promoting a higher pre-dawn xylem water potential, stomatal conductance, resistance to seedling drought, and higher seedling survival in the field. However, the effects of the hydrogel on the physiology of woody species present contradictory responses. Apostol et al. (2009) reported that the use of hydrogel did not promote positive effects on growth or gas exchange in seedlings of Quercus rubras submitted to water deficit. Barbosa et al. (2013) verified that the hydrogel did not interfere in the growth of the seedlings of 30 native tree species, including $H$. impetiginosus, during the 12 months of evaluation.

There were no alterations to the maximum quantum efficiency of photosystem II $\left(\mathrm{F}_{\mathrm{v}} / \mathrm{F}_{\mathrm{m}}\right)$ in the five species evaluated, demonstrating that there was no damage to the photosynthetic apparatus of these plants. However, Gonçalves et al. (2009) observed a reduction in $\mathrm{F}_{\mathrm{v}} / \mathrm{F}_{\mathrm{m}}$ after 14 days of suppression of irrigation in young plants of Carapa guianensis and attributed that the water deficit promoted the reduction of the photochemical activity in response to the decrease of $\mathrm{g}_{\mathrm{s}}$ values, concluding that the photoinhibition occurs in more severe drought conditions. In addition, Trovão et al. (2007) verified that of the 11 species studied, seven did not alter $F_{v} / F_{m}$ in the periods of less water availability, but also that the other four species had minimal reductions, which, according to the mentioned authors, is related to the evolutionary characteristics of these species. Campelo et al. (2015) also found that when the species Calophyllum brasiliensis Cambess., Swietenia macrophylla King. and Handroanthus serratifolius Vahl., were submitted to a more severe water deficit there were negative responses in the maximum photochemical efficiency of photosystem II (PSII).

On the other hand, the absence of a significant differences, at $120 \mathrm{DAT}$, in the maximum quantum efficiency of photosystem II $\left(\mathrm{F}_{\mathrm{v}} / \mathrm{F}_{\mathrm{m}}\right)$, maximum effective photochemical efficiency of PSII (PSII), photochemical extinction coefficient (PQ), and non-photochemical extinction coefficient (NPQ) of the different treatments in Z. joazeiro indicate the high the potential of these plants to settle in low environments with low water availability. These results corroborate the findings of Trovão et al. (2007) which confirming that this species has phenotypic plasticity for adaptations to water stress. Likewise, Souza et al. (2015) have shown that species that remain always green throughout the year, such as Z. joazeiro, exhibit a set of foliar functional traits related to the 
drought tolerance strategy, adapting to different textures of soils and chemical compositions (Costa, Silva, Coelho, Santos, \& Seabra, 2016).

\section{Conclusions}

The photochemical and gas exchange responses of Tabebuia aurea suggest that the waterbox and hydrogel plus bovine manure treatments are more indicated as a water management strategy in the initial growth of this species, as it does not affect the fixation rate of $\mathrm{CO}_{2}$ and phosphorylation. In the species Handroanthus impetiginosus, Crataeva tapia and Erythrina mulungu, the results of the photochemical and gas exchange studies show that the treatments with available water: waterbox and hydrogel are indicated as a water management strategy for these species, sustaining that the hydrogel maintained its increasing effect on the retention and availability of water in the soil during periods of less precipitation.

The species Ziziphus joazeiro has high tolerance to periods of low water availability, maintaining the photosynthetic activities even in the period of low water availability. It is important to study the physiological and photochemical strategies of this species under dry conditions.

\section{References}

Aguiar, S., Souza, Santos, I. S., Arêdes, N., \& Silva, S. (2016). Redes bioma: Informação e comunicação para ação sociopolítica em ecorregiões. Ambiente e Sociedade, $19(3), \quad 233-252$. https://doi.org/10.1590/1809-4422ASOC20140004V1932016

Alves, A, R., Ribeiro, I. B., Sousa, J. R. L., Barros, S. S., \& Sousa, P. S. (2013). Análise da estrutura vegetacional em uma área de caatinga no município de Bom Jesus, Piauí. Revista Caatinga, 26(4), 99-106.

Apostol, K. G., Jacobs, D. F., \& Dumroese, K. (2009). Root desiccation and drought stress responses of bare root Quercus rubra seedlings treated with hydrophilic polymer root dip. Plant and Soil, 315, 229-240. https://doi.org/10.1007/s11104-008-9746-6

Araujo Filho, J. A. (2014). Proposta para a implementação do manejo pastoril sustentável da caatinga (p. 135). MMA-Ministério do Meio Ambiente Secretaria de Biodiversidade e Florestas Diretoria de Ecossistemas.

Arbona, V., Iglesias, D. J., Jacas, J., Primo-Millo, E., Talon, M., \& Cadenas, A. G. (2005). Hydrogel substrate amendment alleviates drought effects on young citrus plants. Plant and Soil, 70(2), 73-82. https://doi.org/10.1007/s11104-004-1160-0

Artur, A. G., Cruz, M. C. P., Ferreira, M. E., Barretto, V. C. M., \& Yagi, R. (2007). Esterco bovino e calagem para a formação de mudas de guanandi. Pesquisa Agropecuária Brasileira, 42(6), 843-850. https://doi.org/10.1590/S0100-204X2007000600011

Barbosa, T. C., Rodrigues, R. R., \& Couto. H. T. Z. (2013). Tamanhos de recipientes e o uso de hidrogel no estabelecimento de mudas de espécies florestais nativas. Hoehnea, 40(3), 537-556. https://doi.org/10.1590/S2236-89062013000300013

Bartieres, E. M. M., Carnevali, N. H. S., Lima, E. S., Carnevali, T. O., \& Mallmann, V. (2016). Hidrogel, calagem e adubação no desenvolvimento inicial, sobrevivência e composição nutricional de plantas híbridas de eucalipto. Pesquisa Florestal Brasileira, 36, 145-151. https://doi.org/10.4336/2016.pfb.36.86.990

Bolhàr-Nordenkampf, H. R., Long, S. P., Baker, N. R., Öquist, G., Schreider, U., \& Lechner E. G. (1989). Chlorophyll fluorescence as probe of the photosynthetic competence of leaves in the field: A review of current instrument. Functional Ecology, 3, 497-514. https://doi.org/10.2307/2389624

Brazil. Distrito Federal, Brasília. (2011). Ministério do Meio Ambiente. Síntese das discussões e recomendações do componente biodiversidade da Caatingar Retrieved from http:/http://www.mma.gov.br/publicacoes/biomas/category/61-caatinga.html?start=20

Campelo, D. H., Lacerda, C. F., Sousa, J. A., Correia, D., Bezerra, A. M. E., Araújo, J. D. M., \& Neves, A. L. R. (2015). Trocas gasosas e eficiência do fotossistema II em plantas adultas de seis espécies florestais em função do suprimento de água no solo. Revista Árvore, 39(5), 973-983. https://doi.org/10.1590/0100-67622015000500020

Chirino, E., Vilagrosa, A., \& Vallejo, V. R.(2011). Using hydrogel and clay to improve the water status of seedlings for dryland restoration. Plant and Soil,344, 99-110. https://doi.org/10.1007/s11104-011-0730-1

Costa, J. D. S., Silva, J. A. B., Coelho, D. S., Santos, I. E. A., \& Seabra, T. X. (2016). Methods for overcoming seed dormancy and the initial growth of Ziziphus joazeiro Mart. in different soils. Revista Caatinga, 29(2), 44-449. https://doi.org/10.1590/1983-21252016v29n221rc 
CPTEC-Proclima. (2016). Programa de monitoramento climático em tempo real da região Nordeste. Retrieved from http://proclima.cptec.inpe.br/balanco_hidrico/balancohidrico.shtml

Cruz, F. R. S., Andrade, L. A., \& Feitosa, R. C. (2016). Produção de mudas de umbuzeiro (Spondias tuberosa Arruda Câmara) em diferentes substratos e tamanho de recipientes. Ciência Florestal, 26(1), 69-80. https://doi.org/10.5902/1980509821092

Felippe, D., Navroski, M. Carlos., Sampietro, J. A., Frigotto. T., Albuquerque, J. A., Mota, C. S., \& Pereira, M. O. (2016). Efeito do hidrogel no crescimento de mudas de Eucalyptus benthamii submetidas a diferentes frequências de irrigação. Floresta, 46(2), 215-225. https://doi.org/10.5380/rf.v46i2.43920

Ferreira, D.F. (2014). Sisvar: A Guide for its Bootstrap procedures in multiple comparisons. Ciência e Agrotecnologia, 38, 109-112. https://doi.org/10.1590/S1413-70542014000200001

Gonçalves, E. R., Ferreira, V. M., Silva, J. V., Endres, L., Barbosa, T. P., \& Duarte, W.G. (2010). Trocas gasosas e fluorescência da clorofila $a$ em variedades de cana-de-açúcar submetidas à deficiência hídrica. Revista Brasileira de Engenharia Agrícola e Ambiental, 14(4), 378-386. https://doi.org/10.1590/S1415-43662010000400006

Köppen, W. (1948). Climatologia: com um estudio de los climas de latierra (p. 478). Fondo de Cultura Economica. Mexico.

Lage-Pinto, F., Bernini, E., Oliveira, J, G., \& Vitória, A, P. (2012). Photosynthetic analyses of two native Atlantic Forest species in regenerative under story of Eucalyptus plantation. Brazilian Journal Plant Physiology,24(2), 95-106.

Larcher, W. (2004). Ecofiosiologia vegetal (p. 531). São Carlos: RiMa.

Maxwell, K., \&Johnson, G. N. (2000). Chlorophyll fluorescence: A practical guide. Journal of Experimental Botany, 51, 659-668. https://doi.org/10.1093/jexbot/51.345.659

Mews, C. L., Sousa, J. R. L., Azevedo, G. T. O. S., \& Souza, A. M. (2015). Efeito do Hidrogel e Uréia na Produção de Mudas de Handroanthus ochraceus (Cham.) Mattos. Floresta e Ambiente, 22(1), $107-116$. https://doi.org/10.1590/2179-8087.080814

Moura, F. B. P., Malhado, M. A. C., \& Ladle, R. J. (2013). Nursing the Caatinga back to health. Journal of Arid Environments, 90, 67-68. https://doi.org/10.1016/j.jaridenv.2012.10.010

Oliveira, A. K. M., \& Gualtieri, S. C.J. (2016). Gas exchange in young plants of Tabebuia aurea (Bignoniaceae Juss.) subjected to flooding stress. Revista Árvore, $40(1)$, 39-49. https://doi.org/10.1590/0100-67622016000100005

Oliveira, A. K. M., Gualtieri, S. C. J., \& Bocchese, R. A. (2011). Gas exchange of potted Tabebuia aurea plants under hydric stress. Acta Scientiarum Agronomy, 33(4), 641-647. https://doi.org/10.4025/actasciagron.v33i4.11254

Osmond, C. B., Björkman, O., \& Anderson, D. J. (1980). Physiological in Processes in Plant Ecology (p. 194). Toward a Synthesis whit Atriplex. Springer Verlag Heidelberg. https://doi.org/10.1007/978-3-642-67637-6

Salinas, A. R., Zelener, N., Craviotto, R. M., \& Bisaro, V.(1996). Respuestas fisiológicas que caracterizan El comportamiento de diferentes cultivares de soja a La deficiencia hídrica em el suelo. Pesquisa Agropecuária Brasileira, 31(5), 331-338.

Sampaio, E. V. S. B., \& Freitas, A. D. (2017). Caatinga: Descrição geral. InF. B. P.Moura,\& J. V. Silva (Eds.), Restauração na Caatinga (p. 250). Maceió: EDUFAL.

Souza, B, C., Oliveira, R. S., Araújo, F. S., Lima, A. L. A., \& Rodal, M. J. N. (2015). Divergências funcionais e estratégias de resistência à seca entre espécies decíduas e sempre verdes tropicais. Rodriguésia, 66(1), 21-32. https://doi.org/10.1590/2175-7860201566102

Trovão, D. M. B. M., Fernandes, P. D., Andrade L. A., \& Neto J. D. (2007). Variações sazonais de aspectos fisiológicos de espécies da Caatinga. Revista Brasileira de Engenharia Agrícola e Ambiental, 11(3), 307-311.https://doi.org/10.1590/S1415-43662007000300010

Xavier, R. A., Dornellas, P. C. (2005). Análise do comportamento das chuvas no município de Arapiraca, região Agreste de Alagoas. Geografia, 14(2), 49-64. 


\section{Copyrights}

Copyright for this article is retained by the author(s), with first publication rights granted to the journal.

This is an open-access article distributed under the terms and conditions of the Creative Commons Attribution license (http://creativecommons.org/licenses/by/4.0/). 